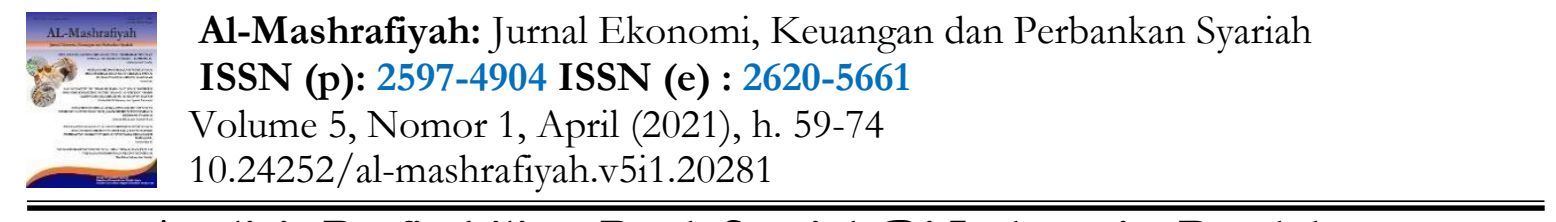

\title{
Analisis Profitabilitas Bank Syariah Di Indonesia: Pendekatan Autoregressive Distributed Lag (ARDL)
}

\author{
Fitri Kurnia Dewi ${ }^{1}$, Heri Sudarso $^{2}$
}

Fakultas Bisnis dan Ekonomika Universitas Islam Indonesia

17313167@students.uii.ac.id¹,heri.sudarsono@uii.ac.id²

Received 14-02-2021; Revised: 12-04-2021; Accepted:27-04-2021

\begin{tabular}{l}
\hline Keywords: \\
Profitability, mudharabah \\
financing, murabahah \\
financing, ARDL.
\end{tabular}

Kata Kunci:

Profitabilitas, pembiayaan mudharabah, pembiayaan murabahah, ARDL.
ABSTRACT

This study aims to analyze the factors that affect the profitability of Islamic Commercial Banks in Indonesia. The dependent variable in this study is Return on Assets (ROA), while the independent variables include CAR, NPF, FDR, BOPO, DPK, mudharabah financing, murabahah financing, BI Rate, and inflation. The research period was from January 2015 to July 2020 using the Autoregressive Distributed Lag (ARDL) approach. This study found that in the short term NPF, FDR, BOPO, DPK, mudharabah financing, murabahah financing, and inflation are significant variables on profitability. Meanwhile, in the long term, the variables that are significant to profitability include $C A R$, BOPO, DPK, and BI Rate. Mudharabah and BOPO financing are the variables that have the biggest influence on profitability. Therefore, Islamic bank management needs to pay attention to the risk of financing using a profit-sharing scheme. In addition, management needs to maintain the level of bank efficiency by taking into account the use of funds to meet operational expense.

\section{ABSTRAK}

Penelitian ini bertujuan untuk menganalisis faktor-faktor yang yang mempengaruhi profitabilitas bank syariah di Indonesia. Penelitian ini mengunakan Return on Asset (ROA) sebagai variable dependen, sedangkan variabel independen antara lain, CAR, NPF, FDR, BOPO, DPK, pembiayaan mudharabah, pembiayaan murabahah, BI Rate, dan inflasi. Periode penelitian dari Januari 2015 hingga Juli 2020 dengan mengunakan pendekatan Autoregressive Distributed Lag (ARDL). Penelitian ini menemukan bahwa dalam jangka pendek NPF, FDR, BOPO, DPK, pembiayaan mudharabah, pembiayaan murabahah, dan inflasi merupakan variabel yang signifikan terhadap profitabilitas. Sedangkan dalam jangka panjang, variabel yang signifikan terhadap profitabilitas meliputi CAR, BOPO, DPK, dan BI Rate. Pembiayaan mudharabah dan BOPO merupakan variabel yang paling berpengaruh terhadap profitabilitas. Oleh karenanya, manajemen bank syariah perlu memperhatikan risiko pada pembiayaan yang mengunakan skema bagi hasil. 


\section{PENDAHULUAN}

Bank syariah di Indonesia berkembangan yang cukup pesat sejak tahun 1998 sampai saaat ini. Perkembangan bank syariah dapat dilihat dari jumlah kantor bank syariah yang sudah menyebar di 34 provinsi di Indonesia (Otoritas Jasa Keuangan, 2020). Perkembangan ini tidak lepas dari meningkatnya peran bank syariah dalam membantu ekonomi masyarakat. Bank syariah mampu menyediakan kebutuhan masyarakat melalui produk pendanaan, pembiayaan dan jasa yang dimiliki. Perkembangan bank Islam juga didukung dengan kwalitas layanan yang berbasis pada teknologi, seperti electronic banking (Sudarsono et al., 2020). Meningkatkan kwalitas layanan menjadikan produk perbankan syariah semakin dikenal dan semakin banyak produk yang dimanfaatkan masyarakat (Nasution, 2020). Semakin banyak produk bank syariah yang manfaatkan masyarakat akan meningkatkan kinerja bank (Anggraini, 2019).

Kinerja bank secara umum dilihat dari kemampuan dalam menghasilkan laba atau profitabilitas. Bank syariah perlu memperhatikan variabel-variabel yang berpengaruh pada profitabilitas agar kinerja dapat meningkat dari waktu ke waktu. Kinerja bank syariah yang baik akan menambah tingkat kepercayaan masyarakat untuk menyimpan dana, mengajukan pembiayaan dan melakukan transaksi dengan bank syariah. Meningkatnya dana akan memberikan peluang bagi bank syariah untuk dapat menyalurkan pembiayaan pada sektor-sektor produktif. Pembiayaan yang cukup tinggi dengan pengelolaan pembiayaan yang baik akan meningkatkan profitabilitas. Profitabilitas digunakan untuk mengukur kinerja keuangan bank syariah secara umum. Alat ukur profitabilitas bank syariah diantaranya adalah rasio laba terhadap aset atau return on asset (ROA). ROA menunjukkan kemampuan bank syariah untuk memanfaat aset yang tersedia untuk menghasilkan laba pada periode tertentu (Syahri \& Harjito, 2020).

\section{Gambar 1. Perkembangan ROA Bank Syariah di Indonesia}

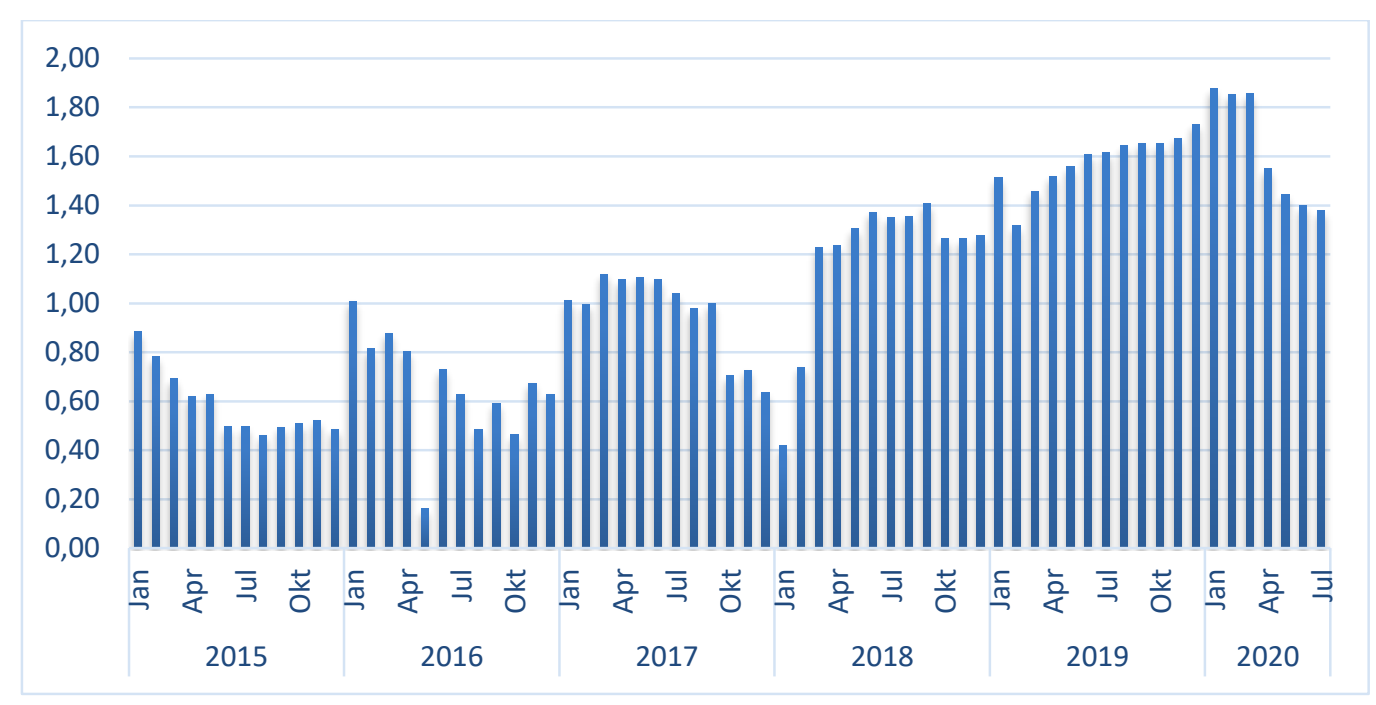

Sumber: Otoritas Jasa Keuangan, 2020

Gambar 1. menunjukkan tingkat ROA bank syariah Januari 2015 hingga Juli 2020 secara umum menunjukkan peningkatan. Nilai ROA terendah terjadi pada Mei 2016, sedangkan nilai tertinggi pada Januari 2020. Nilai ROA mengalami peningkatan yang cukup stabil pada tahun 2019, dimana ROA menunjukkan trend positif dari Januari sampai Desember 2019. Sedangkan pada 2020, pada awal tahun menunjukkan nilai ROA mencapai nilai tertinggi dibanding tahun-tahun sebelumnya, namun pada Maret 2020 menunjukan nilai menurun. Penurunan profitabilitas pada tahun 2020 diakibatkan dengan turunnya kegiatan ekonomi karena Covid-19 yang tercatat mulai masuk di Indonesia pada bulan Februari 2020. 
Ada banyak faktor yang diduga dapat mempengaruhi profitabilitas, baik itu faktor yang bersumber dari internal maupun dari eksternal bank syariah. Berdasarkan penelitian sebelumnya, faktor internal atau faktor spesifik bank yang mempengaruhi ROA bank syariah antara lain ukuran bank, stabilitas keuangan, capital adequacy ratio (CAR), non performing finance (NPF), financial debt ratio (FDR), rasio biaya operasional dengan pendapatan operasional (BOPO), dana pihak ketiga (DPK), pembiayaan mudharabah (PMD) dan pembiayaan murabahab (PMB), SBIS, dan Giro Wajib Minimum (GWM) (Nasution, 2020; Fatmawati \& Hakim, 2020; Anggraini, 2019; Alharbi, 2017; Hanania, 2015; Ubaidillah, 2016; Yundi \& Sudarsono, 2018; Sudarsono, 2017). Sedangkan faktor ekternal atau faktor ekonomi makro yang mempengaruhi ROA adalah pertumbuhan ekonomi (GDP), inflasi (INF), tingkat bunga (BI Rate) dan nilai tukar (Tumewang et al., 2019; Sumarlin, 2016; Ardana, 2018; Alim, 2014; Sahara, 2013)

Penelitian ini mencoba menganalisa tingkat profitabilitas berdasarkan kinerja keuangan bank syariah selama 5 tahun terakhir. Model penelitian ini disusun berdasarkan pada sejumlah penelitian sebelumnya tentang profitabilitas selama 10 tahun terakhir. Variabel internal yang digunakan dalam penelitian ini, antara lain; CAR, NPF, FDR, BOPO, DPK, PMD, dan PMB, sedangkan variabel eksternal, terdiri dari; BI rate dan inflasi (INF). Disamping itu, penelitian ini mencoba menganalisis hubungan variabel internal dan ekternal dengan tingkat profitabilitas dalam jangka pendek dan panjang dengan mengunakan ARDL. Dimana analisis jangka pendek dan jangka pendek dengan ARDL jarang digunakan penelitian tentang profitabilitas sebelumnya.

\section{LANDASAN TEORI}

\section{Profitabilitas Bank syariah}

Bank syariah sebagai lembaga bisnis memiliki tujuan dalam operasinya untuk mendapatkan tingkat profitabilitas yang maksimal. Profitabilitas merupakan kemampuan mengunakan seluruh potensi produksi bank untuk menghasilkan laba dalam periode tertentu (Majid \& Ulina, 2020; Hanania, 2015). Profitabilitas diukur dari rasio pendapatan terhadap aset atau return on assets (ROA) dengan memperhitungkan kemampuan bank syariah dalam memperoleh laba dari aset yang tersedia. Tingkat profitabilitas dengan pendekatan ROA digunakan untuk mengukur kemampuan bank syariah dalam mengelola aktiva yang dimiliki untuk menghasilkan pendapatan. Meningkatnya ROA mencerminkan kinerja keuangan bank dalam menghasilkan profitabilitas sehingga meningkatnya ROA menunjukkan peningkatan profitabilitas (Mahmudah \& Harjanti, 2016). Profitabilitas mendapatkan perhatian pemilik dan pengelola bank syariah karena kegiatan bank pada akhirnya bertujuan untuk mendapatkan laba yang maksimal. Oleh karenanya seluruh strategi dirancang oleh manajemen bank untuk mewujudkan target profitabilitas yang diharapkan (Menicucci \& Paolucci, 2016)

\section{Capital Adequacy Ratio (CAR)}

Capital Adeaquacy Ratio (CAR) adalah sebuah rasio untuk mengukur kecukupan modal yang memperlihatkan sejauh mana kemampuan bank dalam menyediakan modal yang digunakan untuk mengatasi risiko kerugian bank akibat dari kegiatan operasional yang dilakukan (Ubaidillah, 2016). Tingkat CAR berbanding lurus dengan kemampuan bank dalam bertahan dalam situasi krisis atau CAR berhubungan negatif terhadap kemungkinan financial distress. Bank syariah yang memiliki CAR yang tinggi cenderung memiliki kemampuan untuk megoptimalkan dana pada sejumlah unit usaha yang menghasilkan laba. Penelitian Widarjono (2020), Majid dan Ulina (2020), Muhaemin dan Wiliasih (2016) dan Mahmudah dan Harjanti (2016) menemukan pengaruh positif, sedangkan Setiawan dan Andriani (2016) dan Ubaidillah, (2016) menemukan hubungan negatif antara CAR dengan profitabilitas. Di lain pihak, Wibowo dan Syaichu (2013) tidak menemukan pengaruh CAR terhadap profitabilitas. 


\section{Non Performing Financing (NPF)}

Non Performing Financing (NPF) atau risiko pembiayaan merupakan rasio yang digunakan untuk mengetahui debitur atau pengguna dana yang gagal memenuhi kewajibannya terhadap bank pada saat jatuh tempo (Hanania, 2015). Manajemen bank syariah harus mampu menjaga risiko dari kemungkinan melanggar batas ketentuan normatif pemberian pembiayaan dan Batas Maksimum Pemberian Kredit (BMPK) (Ubaidillah, 2016). Apabila bank syariah mampu meminimalisir risiko pembiayaan maka bank syariah akan mampu memaksimalkan profitabilitas. Widarjono, (2020), Yundi dan Sudarsono (2018), Ubaidillah (2016), Muhaemin dan Wiliasih (2016), dan; Yusuf and Mahriana (2016) menemukan hubungan negatif antara NPF dengan profitabilitas. Sementara itu, Wibowo dan Syaichu (2013) menemukan bahwa NPF tidak berpengaruh terhadap profitabilitas.

\section{Financing to Deposit Ratio (FDR)}

Financing to Deposit Ratio (FDR) merupakan rasio pembiayaan terhadap pendanaan yang dimiliki bank dalam periode tertentu (Mahmudah \& Harjanti, 2016). Semakin tinggi FDR menunjukkan dana yang disalurkan bentuk pembiayaan relatif meningkat terhadap pendanaan. Tingkat pembiayaan akan mempengaruhi besarnya potensi pendapatan yang akan diterima dari pihak nasabah. Namun, meningkatnya FDR tidak hanya disebabkan meningkatnya pembiayaan terhadap DPK, tetapi juga disebabkan turunnya DPK terhadap pembiayaan. Oleh karena itu, tingkat pendanaan cenderung mempengaruhi tingkat pembiayaan. Tingkat pembiayaan mempengaruhi besaran profitabilitas yang akan diperoleh bank syariah. Semakin tinggi FDR akan meningkatkan kemampuan bank dalam menghasilkan profitabilitas yang diharapkan. Penelitian Widarjono (2020), Majid \& Ulina (2020), Sudarsono (2017), Muhaemin dan Wiliasih (2016), Ubaidillah, (2016) menemukan pengaruh positif antara FDR dengan profitabilitas. Berbeda dengan penelitian Sumarlin (2016) menemukan bahwa tidak ada pengaruh FDR terhadap profitabilitas

\section{Beban Operasional terhadap Pendapatan Operasional (BOPO)}

Biaya Operasional dibandingkan Pendapatan Operasional (BOPO) atau tingkat efisiensi digunakan untuk mengetahui kemampuan bank dalam mengunakan pendapatan yang diperoleh untuk menutup biaya operasional dalam periode tertentu. Apabila bank syariah mampu memanfaatkan biaya yang dikeluarkan untuk menghasikan pendapatan secara maksimal maka manajemen mampu mengelola biaya secara efisien (Ubaidillah, 2016). Oleh karenanya, manajemen bank berupaya menimalisir tingkat BOPO sebagai upaya untuk memaksimalkan profitabiliytas. Fatmawati dan Hakim (2020), Ubaidillah, (2016) dan Muhaemin \& Wiliasih (2016) menemukan pengaruh negatif BOPO terhadap profitabilitas. Di lain pihak, Wibowo \& Syaichu (2013) menemukan hubungan positif, dan Sudarsono (2017) tidak menemukan pengaruh antara BOPO dengan profitabilitas.

\section{Dana Pihak Ketiga (DPK)}

Dana Pihak Ketiga (DPK) adalah dana yang diperoleh bank syariah dari nasabah perorangan maupun badan usaha yang diinvestasikan atau dititipkan dalam bentuk tabungan, deposito dan giro. Semakin tinggi nilai DPK akan meningkatkan peluang manajemen bank untuk menyalurkan pada beberapa unit usaha yang menguntungkan. Dana bank yang berasal dari DPK kebanyakan disalurkan dalam bentuk pembiayaan yang memiliki potensi menghasilkan profitabilitas lebih tinggi dibanding disimpan dalam bentuk Sertifikat Wadiah Bank Indonesia (SWBI) maupun dalam konversi surat berharga di secondary market. Oleh karenanya, semakin tinggi DPK akan meningkatkan potensi bank syariah untuk menghasilkan laba yang lebih tinggi. Yundi dan Sudarsono (2018); dan, Setiawan dan Andriani (2016) menemukan hubungan positif antara DPK dengan profitabilitas. Di lain pihak, Sudarsono (2017), Yusuf dan Mahriana (2016); dan, Hanania (2015) menemukan dalam jangka panjang DPK berpengaruh negatif terhadap profitabilitas.

\section{Pembiayaan Mudharabah dan Musyarakah}

Pembiayaan mudharabah merupakan suatu akad pembiayaan yang dilakukan oleh dua pihak, yaitu shahibul maal dan mudharib untuk melakukan suatu kegiatan usaha bersama (Hasibuan, 2019; Sudarsono et al, 2019). Bank syariah berperan sebagai shahibul maal yang memberikan $100 \%$ dana yang diminta oleh nasabah 
sebagai mudharib. Keuntungan yang diperoleh bank syariah berupa nisbah bagi hasil yang telah disepakati antar dua pihak yang terikat dalam kesepakatan. Besar kecilnya laba yang diperoleh juga dapat mempengaruhi tingkat profitabilitas dari bank tersebut (Rahman \& Fatmawati, 2020). Sedangkan, pembiayaan murabahah adalah suatu akad jual beli yang dilakukan oleh dua pihak yaitu penjual yang akan menjual barangnya dan pembeli yang akan membeli barang. Dalam transaksi jual beli yang dilakukan dengan akad murabahah, penjual meminta keuntungan yang telah ditetapkan atas terjualnya barang tersebut. Hasibuan (2019); dan, Rahman dan Rochmanika (2012) menemukan hubungan positif antara pembiayaan mudharabah dengan profitabiitas, namun di lain pihak ditemukan pembiayaan murabaha tidak siqnifikan terhadap profitabilitas di Bank Muammalat. Sementara itu, Fatmawati dan Hakim, (2020) menemukan pembiayaan mudharabah dan murababa tidak berpengaruh terhadap profitabilitas. Demikian juga dengan Faradilla et al. (2017) dan Romdhoni \& Yozika (2018) menemukan pembiayaan mudharabah tidak berpengaruh terhadap profitabilitas.

\section{BI Rate}

BI Rate atau suku bunga acuan merupakan suku bunga yang ditetapkan oleh Bank Indonesia sebagai cerminan kebijakan moneter. Apabila tingkat bunga acuan meningkat akan mendorong masyarakat untuk menyimpan dananya ke bank. Namun, kenaikan tingkat bunga acuan ini akan menurunkan keinginan masyarakat untuk mengajukan kredit bank konvensional. Di lain pihak, turunnya tingkat bunga akan menurunkan keinginan masyarakat untuk menyimpan dana tetapi cenderung akan meningkatkan keinginan untuk mengajukan kredit. Bank syariah cenderung mengikuti kebijakan bank konvensional berhubungan dengan tingkat bunga ini agar tidak ditinggal oleh nasabah. Artinya kenaikan BI Rate akan menurunkan nilai pembiayaan bank syariah yang akhirnya akan menurunkan profitabilitas (AlHarbi, 2017). Tumewang, et al. (2019), Hanania (2015), Alim (2014) dan, Sahara, (2013) menemukan hubungan negatif antara tingkat bunga dengan profitabilitas, sedangkan Wibowo dan Syaichu (2013) menemukan bahwa tingkat bunga tidak berpengaruh terhadap profitabilitas.

\section{Inflasi}

Inflasi ditandai dengan naiknya harga-harga barang secara umum yang membuat nilai mata uang mengalami penurunan (Sumarlin, 2016). Inflasi ditandai dengan rendahnya keinginan masyarakat untuk menyimpan uangnya di bank. Masyarakat lebih memilih mengunakan uang yang dimiliki untuk berkonsumsi. Sektor usaha relatif meningkatkan pada saat inflasi tinggi karena output produksi terserap di pasar. Keadaan ini terjadi disebabkan tingkat bunga relatif rendah sehingga pengusaha mendapatkan biaya produksi lebih ringan. Bunga yang ringan meningkatkan produksi perusahaan dan meningkat kemampuan pengusaha untuk membayar kewajibannya kepada bank. Namun, kenaikan inflasi dalam jangka penjang akan mengurangi daya beli masyarakat sehingga mengurangi penyerapan output produksi. Akhirnya, pengusaha akan kesulitan membayar kewajibannya kepada bank sehingga menurunkan profitabilitas bank. Keadaan ini sejalan dengan penelitian Widarjono (2020) dan Tumewang et al. (2019) menemukan hubungan negatif antara inflasi dengan profitabilitas. Di lain pihak Ardana (2018) dan Alim (2014) menemukan bahwa inflasi tidak berpengaruh terhadap profitabilitas. 


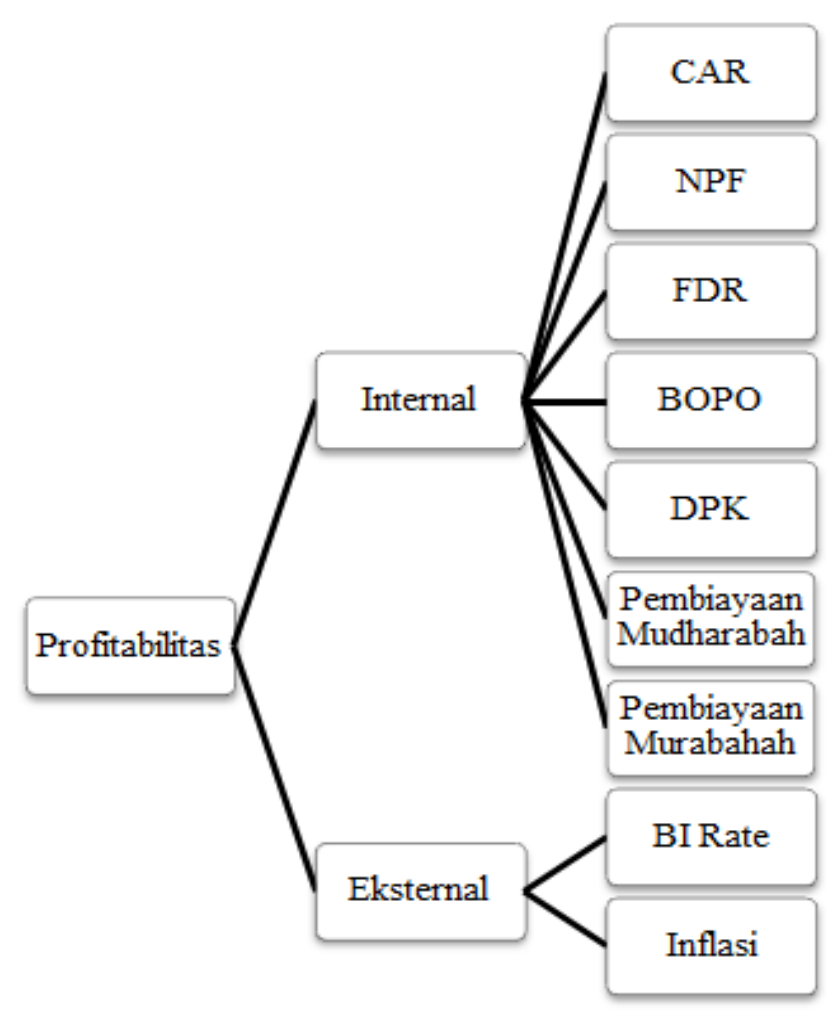

METODE PENELITIAN

Penelitian ini mengunakan data bulanan dari Januari 2015 sampai Juli 2020. Periode ini dipilih karena data yang digunakan adalah data bank umum syariah non Unit Usaha Syariah (UUS). Sedangkan data sebelum 2015 yang disediakan di website Otoriats Jasa Keuangan (OJK) merupakan gabungan data bank umum syarah dan UUS. Sumber data untuk variabel internal, seperti CAR, NPF, FDR, BOPO, DPK, PMD, dan PMB berasal dari website Otoritas Jasa Keuangan (OJK), sedangkan variabel eksternal seperti BI Rate dan INF dari website dari Badan Pusat Statistik (BPS). OJK dan BPS dipilih sebagai sumber utama data karena kedua lembaga ini merupakan lembaga pemerintah yang memiliki kompetensi dalam mengeluarkan data keuangan dan ekonomi di tingkat nasional.

Teknik analisis yang digunakan dalam penelitian ini Autoregressive Distributed Lag (ARDL). Dalam model ARDL terdapat beberapa tahapan pengujian; tahap pertama adalah uji stasioner dengan mengunakan uji Augmented Dickey Fuller (ADF). Uji stasioner untuk mengetahui apakah data runtut waktu mengandung akar unit (unit root). Tahap kedua, adalah uji kointegrasi dengan menggunakan Bound Testing Approach. Uji kointegrasi bertujuan untuk mengetahui ada tidaknya hubungan jangka panjang antar variabel dalam model ARDL. Tahap ketiga adalah estimasi model ARDL dalan jangka pendek dan jangka panjang (Widarjono, 2018).

\section{HASIL DAN PEMBAHASAN}

Tabel 1 menunjukkan deskripsi statistik dari setiap variabel yang digunakan dalam penelitian ini. Nilai rata-rata dari variabel dependen yaitu ROA, sebesar 1,06\% dengan standar deviasi sebesar 0,441\%. Rata-rata dari variabel CAR sebesar 17,659\% dengan standar deviasi sebesar 2,480\%. Rata-rata CAR Bank syariah tersebut tergolong tinggi, yang artinya posisi CAR bank syariah pada Januari 2015 hingga Juli 2020 berada pada posisi yang aman dan menunjukkan bahwa Bank syariah selalu memperhatikan rasio kecukupan modalnya dengan baik. Nilai rata-rata NPF adalah sebesar 4,47\% dengan standar deviasi sebesar 0,845\%. 
Jika dilihat, rata-rata nilai NPF dari bank syariah tersebut masih dalam kategori aman, karena batas maksimal nilai NPF yang baik adalah sebesar 5\%.

Tabel 1. Deskripsi Statistik

\begin{tabular}{ccccc}
\hline Variabel & Mean & Std. Deviasi & Maximum & Minimum \\
\hline ROA & 1.06 & 0.441 & 1.88 & 0.16 \\
CAR & 17.65969477 & 2.480 & 21.39 & 14.09 \\
NPF & 4.47 & 0.845 & 6.17 & 3.23 \\
FDR & 83.07 & 4.619 & 92.56 & 77.02 \\
BOPO & 91.53 & 4.610 & 99.04 & 82.78 \\
DPK & 224.573 & 42866.36964 & 293.374 .23 & 162.816 .58 \\
PMD & 6.673 & 1315.739273 & 8.582 .53 & 4.104 .04 \\
PMB & 109.580 & 12079.14296 & 130.220 .49 & 90.506 .87 \\
BI Rate & 5.630597015 & 1.172 & 7.75 & 4.00 \\
INF & 0.248507463 & 0.305 & 0.97 & -0.45 \\
\hline
\end{tabular}

Sumber: Data Diolah, Excel 2020

Untuk nilai rata-rata FDR adalah sebesar 83,07\% dengan standar deviasi sebesar 4,619\%. Nilai ratarata FDR tersebut masih dalam posisi yang aman, karena batas normal nilai FDR menurut Bank Indonesia adalah sebesar 78\%-100\%. Sedangkan nilai rata-rata BOPO adalah sebesar 91,53\% dengan standar deviasi sebesar $4.610 \%$. Nilai tersebut masih tergolong dalam batas aman, namun juga termasuk dalam kriteria tinggi. Nilai rata-rata DPK adalah sebesar Rp 224,573 miliar. PMD memiliki nilai rata-rata sebesar Rp 6.673 miliar, sedangkan PMB memiliki nilai rata-rata sebesar Rp 109.580 miliar. Jika dilihat dari angka tersebut, PMB memiliki nilai rata-rata yang lebih tinggi, yang berarti PMB lebih berkontribusi pada profitabilitas Bank syariah di Indonesia pada Januari 2015 hingga Juli 2020. Untuk BI Rate, nilai rata-rata adalah sebesar 5,63\% dengan standar deviasi sebesar $1,172 \%$. Untuk inflasi, nilai rata-rata adalah sebesar $0,24 \%$ dengan standar deviasi sebesar $0,305 \%$.

Tabel 2. Hasil Uji Stasioneritas

\begin{tabular}{ccccccc}
\hline \multirow{2}{*}{ Variabel } & \multicolumn{3}{c}{ Level 1(0) } & \multicolumn{3}{c}{ First Difference 1(1) } \\
\cline { 2 - 6 } & Intercept & Trend & None & Intercept & Trend & None \\
\cline { 2 - 6 } ROA & -1.6175 & $-3.7614^{* *}$ & -0.3032 & $-10.0712^{* * *}$ & $-9.9907^{* * *}$ & $-10.1186^{* * *}$ \\
CAR & -0.8311 & -2.1952 & 1.6872 & $-8.0161^{* * *}$ & $-7.9517^{* * *}$ & $-7.7084^{* * *}$ \\
NPF & -1.0278 & $-3.4385^{*}$ & -1.1130 & $-3.8124^{* * *}$ & $-3.7800^{* *}$ & $-3.7015^{* * *}$ \\
FDR & -1.2777 & -0.9388 & -1.2767 & $-10.8915^{* * *}$ & $-10.9159^{* * *}$ & $-10.7868^{* * *}$ \\
BOPO & -0.9140 & $-3.3298^{*}$ & -0.8819 & $-8.4727^{* * *}$ & $-8.4306^{* * *}$ & $-8.4533^{* * *}$ \\
DPK & -0.0777 & -3.0606 & 4.2701 & $-10.7186^{* * *}$ & $-10.6327^{* * *}$ & $-2.7964^{* * *}$ \\
PMD & 0.2949 & $-3.4571^{*}$ & $-2.2063^{* *}$ & $-6.5349^{* * *}$ & $-6.5992^{* * *}$ & $-6.1802^{* * *}$ \\
PMB & -0.4278 & -2.1008 & 2.6293 & $-8.5242^{* * *}$ & $-8.4574^{* * *}$ & $-7.6899^{* * *}$ \\
BI Rate & -1.1420 & -1.3910 & -1.5727 & $-5.6568^{* * *}$ & $-5.5983^{* * *}$ & $-5.4540^{* * *}$ \\
INF & $-7.2588^{* * *}$ & $-7.6662^{* * *}$ & -1.0917 & $-8.5090^{* * *}$ & $-8.4987^{* * *}$ & $-8.5832^{* * *}$ \\
\hline
\end{tabular}


Keterangan:

1. Data diolah dengan menggunakan E-Views 10

2. Keterangan tingkat signifikansi $:\left(^{*}\right)=10 \% ;(* *)=5 \% ;(* * *)=1 \%$

Tabel 2 tersebut menunjukkan hasil dari uji ADF variabel-variabel yang digunakan dalam penelitian ini. Dapat dilihat bahwa variabel-variabel yang digunakan memiliki tingkat stasioneritas yang berbeda. Inflasi stasioner pada tingkat level, yang berarti nilai ADF dari variabel inflasi tersebut $>$ Test Critical Values $(1 \%$, $5 \%$, dan 10\%). Sedangkan variabel lain, meliputi: ROA, CAR, NPF, FDR, BOPO, DPK, PMD, PMB dan BI Rate tidak stasioner pada tingkat level. Hal tersebut menunjukkan bahwa harus dilakukan uji stasioneritas pada tingkat selanjutnya hingga dapat diperoleh hasil yang stasioner. Dari hasil uji stasioneritas pada tingkat first difference menunjukkan hasil bahwa seluruh variabel stasioner, dimana nilai ADF variabel ROA, CAR, NPF, FDR, BOPO, DPK, PMD, PMB, BI Rate, dan inflasi > Test Critical Values (1\%, 5\%, 10\%). Hal tersebut berarti sebagian besar dari variabel-variabel diatas stasioner pada 1(1) dan hanya terdapat satu variabel yang stasioner pada l(1).

Tabel 3. Hasil Estimasi ARDL

\begin{tabular}{|c|c|c|c|c|c|}
\hline Variabel & Coefficient & Std. Error & T-Statistic & Prob. & Keterangan \\
\hline $\mathrm{ROA}(-1)$ & -0.664440 & 0.206627 & -3.215652 & 0.0051 & Signifikan \\
\hline $\operatorname{ROA}(-2)$ & 0.131192 & 0.174747 & 0.750753 & 0.4631 & Tidak Signifikan \\
\hline $\operatorname{ROA}(-3)$ & 0.164822 & 0.098281 & 1.677053 & 0.1118 & Tidak Signifikan \\
\hline $\operatorname{ROA}(-4)$ & -0.172408 & 0.097572 & -1.766987 & 0.0952 & Signifikan \\
\hline CAR & 0.011619 & 0.023207 & 0.500653 & 0.6230 & Tidak Signifikan \\
\hline CAR(-1) & 0.041024 & 0.031538 & 1.300796 & 0.2107 & Tidak Signifikan \\
\hline CAR(-2) & -0.028563 & 0.036231 & -0.788353 & 0.4413 & Tidak Signifikan \\
\hline $\operatorname{CAR}(-3)$ & 0.010669 & 0.034901 & 0.305687 & 0.7636 & Tidak Signifikan \\
\hline CAR $(-4)$ & 0.071252 & 0.035907 & 1.984381 & 0.0636 & Signifikan \\
\hline $\mathrm{NPF}$ & 0.138642 & 0.068580 & 2.021620 & 0.0592 & Signfikan \\
\hline NPF(-1) & -0.132173 & 0.053438 & -2.473375 & 0.0242 & Signifikan \\
\hline NPF(-2) & -0.007939 & 0.060208 & -0.131866 & 0.8966 & Tidak Signifikan \\
\hline $\operatorname{NPF}(-3)$ & -0.114730 & 0.070260 & -1.632935 & 0.1209 & Tidak Signifikan \\
\hline NPF(-4) & 0.146710 & 0.067677 & 2.167804 & 0.0447 & Signifikan \\
\hline FDR & 0.063892 & 0.029604 & 2.158234 & 0.0455 & Signifikan \\
\hline $\operatorname{FDR}(-1)$ & -0.018514 & 0.021131 & -0.876131 & 0.3932 & Tidak Signifikan \\
\hline $\operatorname{FDR}(-2)$ & -0.021275 & 0.022001 & -0.967019 & 0.3471 & Tidak Signifikan \\
\hline $\operatorname{FDR}(-3)$ & -0.019839 & 0.025049 & -0.792004 & 0.4393 & Tidak Signifikan \\
\hline $\operatorname{FDR}(-4)$ & 0.010770 & 0.010241 & 1.051714 & 0.3077 & Tidak Signifikan \\
\hline BOPO & -0.149046 & 0.013179 & -11.30945 & 0.0000 & Signifikan \\
\hline BOPO(-1) & -0.082381 & 0.033436 & -2.463865 & 0.0247 & Signifikan \\
\hline BOPO(-2) & 0.040410 & 0.030800 & 1.312013 & 0.2070 & Tidak Signifikan \\
\hline DPK & 0.009081 & 0.007727 & 1.175210 & 0.2561 & Tidak Signifikan \\
\hline $\mathrm{DPK}(-1)$ & -0.005001 & 0.006764 & -0.739407 & 0.4697 & Tidak Signifikan \\
\hline $\mathrm{DPK}(-2)$ & -0.003808 & 0.007267 & -0.524071 & 0.6070 & Tidak Signifikan \\
\hline $\mathrm{DPK}(-3)$ & -0.020395 & 0.009597 & -2.125161 & 0.0485 & Signifikan \\
\hline PMD & -0.291998 & 0.081554 & -3.580413 & 0.0023 & Signifikan \\
\hline $\operatorname{PMD}(-1)$ & 0.168873 & 0.078556 & 2.149722 & 0.0463 & Signifikan \\
\hline $\operatorname{PMD}(-2)$ & 0.054873 & 0.075608 & 0.725752 & 0.4779 & Tidak Signifikan \\
\hline $\operatorname{PMD}(-3$ & -0.113173 & 0.065574 & -1.725896 & 0.1025 & Tidak Signifikan \\
\hline
\end{tabular}




\begin{tabular}{|c|c|c|c|c|c|}
\hline $\operatorname{PMD}(-4)$ & 0.102746 & 0.058796 & 1.747501 & 0.0986 & Signifikan \\
\hline PMB & -0.031307 & 0.014546 & -2.152228 & 0.0460 & Signifikan \\
\hline $\operatorname{PMB}(-1)$ & 0.008422 & 0.014160 & 0.594781 & 0.5598 & Tidak Signifikan \\
\hline $\operatorname{PMB}(-2)$ & -0.008066 & 0.015124 & -0.533324 & 0.6007 & Tidak Signifikan \\
\hline $\operatorname{PMB}(-3)$ & 0.036429 & 0.012807 & 2.844347 & 0.0112 & Signifikan \\
\hline $\operatorname{PMB}(-4)$ & 0.017192 & 0.008376 & 2.052443 & 0.0559 & Signifikan \\
\hline BI Rate & -0.191029 & 0.070923 & -2.693482 & 0.0154 & Signifikan \\
\hline BI Rate(-1) & -0.012310 & 0.097689 & -0.126016 & 0.9012 & Tidak Signifikan \\
\hline BI Rate(-2) & 0.128496 & 0.113413 & 1.132997 & 0.2729 & Tidak Signifikan \\
\hline BI Rate(-3) & -0.237086 & 0.128409 & -1.846333 & 0.0823 & Signifikan \\
\hline BI Rate(-4) & 0.189930 & 0.087176 & 2.178702 & 0.0437 & Signifikan \\
\hline INF & 0.109487 & 0.044175 & 2.478484 & 0.0240 & Signifikan \\
\hline $\operatorname{INF}(-1)$ & 0.070489 & 0.049425 & 1.426180 & 0.1719 & Tidak Signifikan \\
\hline $\operatorname{INF}(-2)$ & -0.003357 & 0.041537 & -0.080809 & 0.9365 & Tidak Signifikan \\
\hline $\operatorname{INF}(-3)$ & -0.060051 & 0.041344 & -1.452462 & 0.1646 & Tidak Signifikan \\
\hline C & 19.01873 & 7.114816 & 2.673116 & 0.0160 & Signifikan \\
\hline \multicolumn{6}{|c|}{ Nilai Statistik } \\
\hline R-squared & \multicolumn{5}{|c|}{0.997246} \\
\hline Adjusted R- & \multicolumn{5}{|c|}{0.989957} \\
\hline F-statistic & \multicolumn{5}{|c|}{136.8038} \\
\hline Prob(F-stati & \multicolumn{5}{|c|}{0.000000} \\
\hline \multicolumn{6}{|c|}{ Diagnostic } \\
\hline LM 1 & \multicolumn{5}{|c|}{0.1035} \\
\hline LM 2 & \multicolumn{5}{|c|}{0.0005} \\
\hline ARCH 1 & \multicolumn{5}{|c|}{0.1128} \\
\hline ARCH 2 & \multicolumn{5}{|c|}{0.2255} \\
\hline
\end{tabular}

Sumber: Data Diolah E-Views 10, Tahun 2020

Tabel 3 menunjukkan hasil estimasi ARDL tersebut menggunakan model ARDL (4, 4, 4, 4, 2, 3, 4, $4,4,3)$. Dalam model tersebut menunjukkan bahwa banyak variabel yang signifikan, walaupun terdapat variabel yang tidak signifikan di beberapa lag. Dengan demikian, model ARDL dapat dilanjutkan ke tahap berikutnya. Sedangkan nilai LM (1), $\mathrm{LM}(2), \mathrm{ARCH}(1)$, dan $\mathrm{ARCH}(2)$ menunjukkan bahwa tidak terdapat masalah autokorelasi maupun heteroskedastisitas pada data yang digunakan, sehingga model ARDL dapat dilanjutkan ke tahap berikutnya. Sedangkan nilai Adjusted R-Squared dan R-Squared bernilai relatif tinggi yaitu 0.989957 dan 0.997246 , yang berarti $98.9 \%$ dan $99.7 \%$ variasi dari profitabilitas (ROA) mampu dijelaskan oleh masing-masing variabel bebas yang terpilih dalam model ARDL.

Tabel 4. Hasil Uji Kointegrasi

\begin{tabular}{ccc}
\hline \multicolumn{3}{c}{ F-Statistic Value = 3.568396 } \\
\hline Significance & 10 Bound (Lower Bound) & 11 Bound (Upper Bound) \\
$10 \%$ & 1.8 & $2.8 \%$ \\
$5 \%$ & $2.04 \%$ & $2.08 \%$ \\
$1 \%$ & $2.5 \%$ & $3.68 \%$ \\
\hline
\end{tabular}

Sumber: Data Diolah E-Views 10, Tahun 2020

Tabel 4. menunjukan hasil uji kointegrasi yang menyebutkan bahwa nilai $\mathrm{F}$ hitung dan nilai $\mathrm{F}$ kritis pada berbagai tingkat signifikansi. Nilai F kritis terdiri dari F kritis batas atas atau upper bound dan F kritis 
batas bawah atau lower bound. Hasil yang diperoleh adalah nilai F hitung > nilai F kritis pada batas $1(0)$ dan 1(1) yaitu sebesar 3,568396 > 1,8 dan 2,8. Maka hasil tersebut menunjukkan bahwa kita menolak $\mathrm{H}_{0}$, yang berarti data-data tersebut memiliki nilai kointegrasi. Artinya, terdapat hubungan jangka panjang antara variabel dependen yaitu profitabilitas dengan variabel independen yaitu CAR, NPF, FDR, BOPO, DPK, PMD, PMB, BI Rate, dan inflasi.

Tabel 5. Hasil Estimasi ARDL Jangka Pendek

\begin{tabular}{|c|c|c|c|c|c|}
\hline Variabel & Coefficients & Std. Error & T-Statistic & Prob. & Keterangan \\
\hline $\mathrm{D}(\mathrm{ROA}(-1))$ & -0.123606 & 0.118313 & -1.044738 & 0.3108 & Tidak Signifikan \\
\hline $\mathrm{D}(\mathrm{ROA}(-2))$ & 0.007586 & 0.050514 & 0.150174 & 0.8824 & Tidak Signifikan \\
\hline $\mathrm{D}(\mathrm{ROA}(-3))$ & 0.172408 & 0.048362 & 3.564969 & 0.0024 & Signifikan \\
\hline $\mathrm{D}(\mathrm{CAR})$ & 0.011619 & 0.014618 & 0.794802 & 0.4377 & Tidak Signifikan \\
\hline $\mathrm{D}(\mathrm{CAR}(-1))$ & -0.053358 & 0.015456 & -3.452199 & 0.0030 & Signifikan \\
\hline $\mathrm{D}(\mathrm{CAR}(-2))$ & -0.081921 & 0.018036 & -4.542112 & 0.0003 & Signifikan \\
\hline $\mathrm{D}(\mathrm{CAR}(-3))$ & -0.071252 & 0.018744 & -3.801401 & 0.0014 & Signifikan \\
\hline $\mathrm{D}(\mathrm{NPF})$ & 0.138642 & 0.033009 & 4.200120 & 0.0006 & Signifikan \\
\hline $\mathrm{D}(\mathrm{NPF}(-1))$ & -0.024041 & 0.030519 & -0.787745 & 0.4417 & Tidak Signifikan \\
\hline $\mathrm{D}(\mathrm{NPF}(-2))$ & -0.031980 & 0.029548 & -1.082336 & 0.2942 & Tidak Signifikan \\
\hline $\mathrm{D}(\mathrm{NPF}(-3))$ & -0.146710 & 0.034395 & -4.265474 & 0.0005 & Signifikan \\
\hline $\mathrm{D}(\mathrm{FDR})$ & 0.063892 & 0.013921 & 4.589539 & 0.0003 & Signifikan \\
\hline $\mathrm{D}(\mathrm{FDR}(-1))$ & 0.030344 & 0.013535 & 2.241981 & 0.0386 & Signifikan \\
\hline $\mathrm{D}(\mathrm{FDR}(-2))$ & 0.009069 & 0.012130 & 0.747649 & 0.4649 & Tidak Signifikan \\
\hline $\mathrm{D}(\mathrm{FDR}(-3))$ & -0.010770 & 0.006704 & -1.606552 & 0.1266 & Tidak Signifikan \\
\hline $\mathrm{D}(\mathrm{BOPO})$ & -0.149046 & 0.007096 & -21.00382 & 0.0000 & Signifikan \\
\hline $\mathrm{D}(\mathrm{BOPO}(-1))$ & -0.040410 & 0.015888 & -2.543372 & 0.0210 & Signifikan \\
\hline $\mathrm{D}(\mathrm{DPK})$ & 0.009081 & 0.003678 & 2.468810 & 0.0245 & Signifikan \\
\hline $\mathrm{D}(\mathrm{DPK}(-1))$ & 0.024203 & 0.005112 & 4.734996 & 0.0002 & Signifikan \\
\hline $\mathrm{D}(\mathrm{DPK}(-2))$ & 0.020395 & 0.005143 & 3.965183 & 0.0010 & Signifikan \\
\hline $\mathrm{D}(\mathrm{PMD})$ & -0.291998 & 0.043003 & -6.790107 & 0.0000 & Signifikan \\
\hline $\mathrm{D}(\operatorname{PMD}(-1))$ & -0.044445 & 0.035371 & -1.256532 & 0.2259 & Tidak Signifikan \\
\hline $\mathrm{D}(\operatorname{PMD}(-2))$ & 0.010427 & 0.033156 & 0.314494 & 0.7570 & Tidak Signifikan \\
\hline $\mathrm{D}(\operatorname{PMD}(-3))$ & -0.102746 & 0.033941 & -3.027153 & 0.0076 & Signifikan \\
\hline $\mathrm{D}(\mathrm{PMB})$ & -0.031307 & 0.007675 & -4.079125 & 0.0008 & Signifikan \\
\hline $\mathrm{D}(\mathrm{PMB}(-1))$ & -0.045554 & 0.008952 & -5.088667 & 0.0001 & Signfikan \\
\hline $\mathrm{D}(\mathrm{PMB}(-2))$ & -0.053621 & 0.010240 & -5.236623 & 0.0001 & Signifikan \\
\hline $\mathrm{D}(\operatorname{PMB}(-3))$ & -0.017192 & 0.004859 & -3.538240 & 0.0025 & Signifikan \\
\hline D(BI_RATE) & -0.191029 & 0.044595 & -4.283641 & 0.0005 & Signifikan \\
\hline D(BI_RATE(-1)) & -0.081340 & 0.043605 & -1.865362 & 0.0795 & Signifikan \\
\hline D(BI_RATE(-2)) & 0.047156 & 0.047426 & 0.994309 & 0.3340 & Tidak Signifikan \\
\hline D(BI_RATE(-3)) & -0.189930 & 0.054477 & -3.486436 & 0.0028 & Signifikan \\
\hline $\mathrm{D}(\mathrm{INF})$ & 0.109487 & 0.022963 & 4.767901 & 0.0002 & Signifikan \\
\hline $\mathrm{D}(\mathrm{INF}(-1))$ & 0.063407 & 0.022392 & 2.831740 & 0.0115 & Signifikan \\
\hline $\mathrm{D}(\mathrm{INF}(-2))$ & 0.060051 & 0.021261 & 2.824476 & 0.0117 & Signifikan \\
\hline CointEq $(-1)^{*}$ & -1.540834 & 0.195149 & -7.895693 & 0.0000 & Signifikan \\
\hline
\end{tabular}

Sumber: Data Diolah Eviews 10, Tahun 2020 
Dari hasil estimasi ARDL jangka pendek pada tabel 5, diperoleh nilai CointEq (-1). Variabel tersebut merupakan variabel yang menunjukkan error correction dari model yang digunakan. Nilai CointE $q(-1)$ dari hasil tersebut menunjukkan negatif dan signifikan, dimana nilai CointEq(-1) yang memiliki probabilitas sebesar 0.0000 dan coefficient sebesar -1.540834 , signifikan di berbagai tingkat alpha yaitu 1\%, 5\%, dan $10 \%$. Artinya, model ARDL adalah valid. Selain itu, dari hasil tersebut juga diperoleh nilai probabilitas t-statistik, dimana dari nilai tersebut yang dibandingkan dengan nilai tingkat signifikansi akan diketahui ada atau tidaknya pengaruh dari variabel independen terhadap variabel dependen. Nilai probabilitas yang lebih kecil dari nilai tingkat signifikansi, dapat dikatakan bahwa terdapat pengaruh yang signifikan dari variabel independen terhadap variabel dependen.

Tabel 6. Hasil Estimasi ARDL Jangka Panjang

\begin{tabular}{cccccc}
\hline Variabel & Coefficient & Std. Error & T-Statistic & Prob. & Keterangan \\
\hline CAR & 0.068795 & 0.024410 & 2.818263 & 0.0118 & Signifikan \\
NPF & 0.019801 & 0.094221 & 0.210159 & 0.8360 & Tidak Signifikan \\
FDR & 0.009757 & 0.012057 & 0.809225 & 0.4296 & Tidak Signifikan \\
BOPO & -0.123970 & 0.008072 & -15.35883 & 0.0000 & Signifikan \\
DPK & -0.013060 & 0.001756 & -7.437599 & 0.0000 & Signifikan \\
PMD & -0.051063 & 0.044363 & -1.151015 & 0.2657 & Tidak Signifikan \\
PMB & 0.014712 & 0.010003 & 1.470737 & 0.1596 & Tidak Signifikan \\
BI Rate & -0.079178 & 0.036741 & -2.155017 & 0.0458 & Signifikan \\
INF & 0.075654 & 0.058412 & 1.295169 & 0.2126 & Tidak Signifikan \\
C & 12.34314 & 3.127020 & 3.947255 & 0.0010 & Signifikan \\
\hline
\end{tabular}

Sumber: Data Diolah E-Views, Tahun 2020

Tabel 6 menunjukkan hasil estimasi jangka panjang, dimana CAR berpengaruh positif dan signifikan terhadap profitabilitas. Artinya, dengan semakin meningkatnya nilai CAR bank syariah berarti semakin baik posisi modal yang dimiliki oleh bank tersebut. Rasio kecukupan modal ini dapat digunakan bank syariah untuk menghadapi risiko kerugian yang mungkin terjadi. Penelitian ini sesuai dengan penelitian Widarjono (2020), Majid dan Ulina (2020), Muhaemin dan Wiliasih (2016), Mahmudah dan Harjanti (2016) yang menunjukkan hubungan positif dan signifikan antara variabel CAR dan ROA. Namun, hasil penelitian ini tidak sejalan dengan penelitian Setiawan dan Andriani (2016), Ubaidillah (2016) dan Sumarlin (2016), yang menunjukkan bahwa variabel CAR memiliki hubungan negatif dan signifikan terhadap ROA.

NPF tidak berpengaruh terhadap profitabilitas dalam jangka panjang. Artinya, tinggi rendahnya tingkat NPF tidak mempengaruhi tingkat profitabilitas bank syariah secara langsung. Hasil penelitian ini sesuai dengan penelitian yang dilakukan oleh Wibowo dan Syaichu (2013) yang menemukan bahwa NPF tidak berpengaruh terhadap ROA. Temuan ini menunjukkan bahwa manajemen bank syariah mampu mengelola dana yang disalurkan pada masing-masing jenis pembiayaan. Prosedur untuk memberikan pembiayaan melalui financial scoring menjadi pintu awal bagi bank untuk melihat tingkat keamanan pembiayaan yang akan disalurkan. Financial scoring ini yang menjadikan bank mampu memprediksi risiko pembiayaan di masa depan. Nilai NPF selama periode penelitian menunjukkan bahwa manajemen bank relatif mampu meminimalisir meningkatnya risiko pembiayaan diluar target yang diharapkan. Walaupun hasil penelitian ini tidak sesuai dengan penelitian Widarjono, (2020), Yundi dan Sudarsono (2018), Ubaidillah (2016), Muhaemin dan Wiliasih (2016) dan Yusuf dan Mahriana (2016) yang menemukan pengaruh negatif antara NPF dengan profitabilitas. Namun, hasil ini menunjukan hasil positif bagi pengelolaan risiko pembiayaan di bank syariah.

FDR tidak berpengaruh terhadap profitabilitas dalam jangka panjang. Nilai pendanaan yang diperoleh dari DPK menunjukan peningkatan yang stabil, demikian juga dengan nilai pembiayan yang disalurkan kepada sektor produksi, konsumtif maupun jasa. Manajemen bank syariah selama periode 
penelitian mampu menjaga likuditas dengan baik dengan menjaga proporsi dana yang disalurkan dan dana yang masuk. Orientasi bisnis bank syariah tidak semata-mata pada upaya memaksimalkan profitabilitas namun juga memperhitungkan tingkat keamanan dalam mengelolaan dana milik principle. Hasil penelitian ini sesuai dengan penelitian Sumarlin (2016) yang menemuan bahwa tidak ada pengaruh FDR terhadap profitabilitas. Namun, hasil ini berbeda dengan penelitian Widarjono (2020), Majid dan Ulina (2020), Sudarsono (2017), Muhaemin dan Wiliasih (2016), dan Ubaidillah, (2016) yang menemukan pengaruh positif antara FDR dengan profitabilitas.

BOPO berpengaruh negatif terhadap profitabilitas dalam jangka panjang. Manajemen bank mampu memaksimalkan biaya operasional yang dikeluarkan untuk dapat mengoptimalkan laba yang akan diperoleh bank. Biaya yang dikeluarkan bank syariah pada periode penelitian selaras dengan target pendapatan bank diharapkan oleh manajemen bank. Artinya manajemen bank cukup hati-hati dalam menentukan kebijakan yang berhubungan dengan pengeluaran atau biaya bank (overbead cost). Kebijakan manajemen disebut efisien apabila besarnya biaya operasional berkorelasi positif terhadap besarnya pendapatan yang diharapkan. Dari hasil olah data menunjukkan bahwa manajemen bank mampu mengelola biaya operasional sehingga dapat memaksimalkan profitabilitas bank. Hasil ini sesuai dengan temuan Fatmawati dan Hakim (2020), Ubaidillah, (2016) dan Muhaemin dan Wiliasih (2016) menemukan bahwa BOPO berpengaruh negatif terhadap profitabilitas. Namun, penelitian ini tidak sesuai dengan penelitian Sudarsono (2017) dan Wibowo \& Syaichu (2013)

DPK berpengaruh negatif terhadap profitabilitas bank syariah. Hasil penelitian ini sesuai dengan penelitian yang dilakukan oleh Sudarsono (2017) dan Yusuf dan Mahriana (2016) dan Hanania (2015) yang menemukan dalam jangka panjang DPK berpengaruh negatif terhadap profitabilitas. Tingkat DPK tidak berpengaruh secara langsung pada manajemen bank untuk menyalurkan dana dalam bentuk pembiayaan. Hubungan negatif antara DPK dengan profitabilitas disebabkan oleh kenaikan DPK tidak berpengaruh terhadap tingkat pembiayaan atau kenaikan pembiayaan tidak dipengaruh oleh besarnya nilai DPK. Manajemen bank lebih mempertimbangkan tingkat keamanaan pembiayaan sehingga lebih hati-hati dalam memberikan pembiayaan kepada nasabah. Keadaaan ini yang menyebabkan perkembangan DPK dengan pembiayaan cenderung kurang selaras pada periode penelitian. Hasil ini berbeda dengan penelitian Setiawan dan Andriani (2016) dan Yundi dan Sudarsono (2018) yang menemukan hubungan positif antara DPK dan profitabilitas.

Pembiayaan mudharabah tidak berpengaruh terhadap profitabilitas bank syariah. Pembiayaan mudharabah merupakan pembiayaan yang nilai pengembaliannya tergantung dari tingkat pendapatan usaha yang diperoleh nasabah. Bank akan mendapatkan tambahan dari pengembalian pembiayaan selama nasabah mendapatkan keuntungan. Bank tidak bisa mengharapakan mendapatkan pengembalian pendapatan dari nasabah dalam jumlah yang konsisten dari waktu ke waktu. Manajemen bank cenderung meminimaliris dana yang dimiliki untuk disalurkan pada pembiayaan mudharabah karena pembiayaan ini tidak bisa dipastikan besarnya laba yang diberikan bank. Keadaan ini yang menyebabkan pembiayaan mudharabah tidak berpengaruh terhadap profitabilitas. Hasil penelitian ini sejalan dengan penelitian yang dilakukan oleh Fatmawati dan Hakim (2020), Faradilla et al. (2017) dan Romdhoni \& Yozika (2018) yang menemukan bahwa pembiayaan mudharabah tidak berpengaruh terhadap profitabilitas

Sementara, itu pembiayaan murabahah berpengaruh positif terhadap profitabilitas bank syariah. Manajemen bank syariah lebih banyak menyalurkan pembiayaan dalam bentuk murabahab karena pembiayaan ini relatif lebih pasti dalam memberikan laba. Bank syariah sebagai lembaga bisnis membutuhkan kepastian pendapatan yang diterima masa depan untuk dijadikan dasar bagi manajemen dalam membuat kebijakan. Demikian juga pihak pemilik bank (principle) membutuhkan kepastian bahwa bank yang dimiliki jauh dari kemungkinan rugi atau bangkrut. Pemilik dana tabungan dan deposito juga tidak mau rugi dengan ketidakpastian bagi hasil yang diperoleh. Oleh karena manajemen bank lebih banyak menyalurkan pembiayaan dalam bentuk murababa untuk menghasilkan pendapatan yang diharapkan. Hasil ini sama dengan temuan Fatmawati dan Hakim (2020) dan Rahman dan Rochmanika (2012) dimana pembiayaan murababah berpengaruh positif untuk meningkatkan profitabilitas perbankan syariah. 
BI Rate atau suku bunga acuan berpengaruh negatif terhadap profitabilitas bank syariah. Hasil ini sejalan dengan penelitian Tumewang, et al. (2019), Hanania (2015), Alim (2014) dan Sahara, (2013) yang menyebutkan bahwa suku bunga acuan berpengaruh negatif terhadap profitabilitas bank syariah. Kenaikan tingkat bunga menimbulkan konswensi bagi meningkatnya beban modal perusahaan karena tingkat bunga merupakan harga dari utang (credit). Apabila tingkat bunga tinggi maka nasabah akan mendapatkan beban untuk mengembalikan kelebihan dari pokok utang yang lebih tinggi. Oleh karena itu, kebanyakan nasabah mengurangi utang ke bank pada saat tingkat bunga meningkat. Bank syariah walaupun tidak mengunakan tingkat bunga tetapi bank syariah masih mengunakan tingkat bunga sebagai acuan untuk menentukan margin dan nisbah bagi hasil. Keadaan ini yang menyebabkan dampak meningkatnya margin dan nisbah bagi hasil pada bank syariah, tidak jauh berbeda dengan tingkat bunga di bank konvesional

Inflasi tidak berpengaruh terhadap profitabilitas bank syariah. Artinya, naiknya tingkat inflasi tidak mempengaruhi tingkat profitabilitas bank syariah. Penelitian ini sesuai dengan penelitian Ardana (2018) dan Alim (2014) yang menemukan bahwa inflasi tidak berpengaruh terhadap profitabilitas. Namun, penelitian ini tidak sesuai dengan penelitian yang dilakukan oleh Widarjono (2020) dan Tumewang et al. (2019) dan Hidayati (2014) yang menemukan bahwa inflasi mempunyai pengaruh positif terhadap profitabilitas bank syariah. Inflasi akan menyebabkan daya beli masyarakat menurun sehingga mempengaruhi menurunnya output produksi. Pendapatan pengusaha akan menurun apabila sumber pendapat yang diperoleh tidak terserap oleh pasar dikarena harga barang dan jasa relatif mahal. Keadaan ini yang menyebabkan kemampuan pengusaha untuk mengembalikan pembiayaan dan margin atau bagi hasilnya kepada bank syariah menurun sehingga profitabilitas yang diperoleh bank syariah menurun.

\section{PENUTUP}

Berdasarkan olah data dapat disimpulkan bahwa dalam jangka pendek maupun jangka panjang, variabel CAR, NPF, FDR, BOPO, DPK, PMD, PMB, BI Rate, dan inflasi memiliki pengaruh yang berbeda-beda terhadap tingkat profitabilitas. Dalam jangka pendek, variabel internal bank syariah yang mempengaruhi profitabilitas adalah NPF, FDR, BOPO, DPK, dan PMB. Dalam jangka panjang, CAR dan PMB memiliki pengaruh yang positif, sedangkan BOPO dan BI Rate berpengaruh negatif terhadap profitabilitas. Sementara itu, NPF, FDR, DPK, PMD dan inflasi tidak berpengaruh terhadap profitabilitas.

Manajemen bank syariah perlu mempertahankan prinsip kehati-harian dalam mengelola pembiayaan agar mengurangi risiko pembiayaan. Sikap manajemen bank lebih memprioritaskan pembiayaan murabahah merupakan konswensi dari usaha untuk dapat menghasilkan laba secara maksimal. Disamping itu, kebijakan ini merupakan upaya untuk menghindari risiko ketidakpastian pada pembiayaan mudharabah. Selain itu, usaha manajemen bank dalam meningkatkan efisiensi dengan memaksimal nilai tambah dari pengeluaran bank untuk memaksimal pendapatan perlu dipertahankan. Sikap manajemen bank untuk menjadikan tingkat bunga sebagai acuan dalam menentukan margin dan nisbah bagi hasil perlu dikurangi agar terjebak pada sistem ribawi.

Penelitian ini memiliki sejumlah keterbatasan antara lain; pertama, jumlah observasi sebanyak 67 bulan relatif kurang untuk mendapatkan hasil olah data yang komprehensif. Oleh karena itu direkomendasikan untuk menambah data observasi atau mengunakan data panel dari setiap 14 bank syariah dari tahun 2015 sampai 2020. Kedua, jumlah variabel eksternal atau makro perlu ditambah untuk mendapatkan informasi yang lebih berimbang antara variabel internal dan eksternal yang mempengaruhi profitabilitas. Direkomendasikan variabel pertumbuhan ekonomi atau GDP, nilai tukar atau investasi bisa dimasukkan sebagai variabel makro ekonomi. Ketiga, variabel yang digunakan kebanyakan mengunakan variabel kuantitatif sehingga penelitian ini belum dapat mencerna kebijakan dibalik munculnya data tersebut secara utuh. Seharusnya data kualitatif perlu dipertimbangkan sebagai bagian penting dalam model penelitian profitabilitas berikutnya. 


\section{DAFTAR PUSTAKA}

Alharbi, A.T. (2017), Determinants of Islamic banks' profitability: international evidence, International Journal of Islamic and Middle Eastern Finance and Management, 10(3), 331-350. https://doi.org/10.1108/IMEFM$\underline{12-2015-0161}$

Alim, S. (2014). Analisis Pengaruh Inflasi dan Bi Rate terhadap Return on Assets (Roa) Bank syariah di Indonesia. Jurnal Ekonomi Modernisasi, 10(3), 201-220. https://doi.org/10.21067/jem.v10i3.785

Anggraini, M. (2019). Islamic Banking Development and Economic Growth: A Case Study of Indonesia. Asian Journal of Islamic Management, 1(1), 51-65. https://doi.org/10.1108/AJIM.vol1.iss1.art5

Ardana, Y. (2018). Faktor Eksternal dan Internal yang Mempengaruhi Profitabilitas Bank syariah di Indonesia. Cakrawala, 13(1), 51. https://doi.org/10.31603/cakrawala.v13i1.2042

Badan Pusat Statistik. 2020. Indeks Harga Konsumen dan Inflasi Bulanan Indonesia tahun 2006-2020. Diakses pada 10 Oktober 2020, dari www.bps.go.id

Badan Pusat Statistik. 2020. BI Rate. Diakses pada 10 Oktober 2020, dari www.bps.go.id

Faradilla, C., Muhammad, A., \& Shabri, M. (2017). Pengaruh Pembiayaan Murabahah, Istishna, Ijarah, Mudharabah dan Musyarakah terhadap Profitabilitas Bank syariah di Indonesia. Jurnal Magister Akuntansi, 6(3), 10-18.

Fatmawati, N. L., \& Hakim, A. (2020). Analisis Tingkat Profitabilitas Perbankan Syariah di Indonesia. Jurnal Baabu Al-Imi Ekonomi dan Perbankan Syariah, 5, 1-15. https://doi.org/10.29300/ba.v4i2

Hanania, L. (2015). Faktor Internal dan Eksternal yang Mempengaruhi Profitabilitas Perbankan Syariah dalam Jangka Pendek dan Jangka Panjang. Perbanas Review, 1(1), 151-168.

Hasibuan, F. U. (2019). Analisis Pengaruh Pembiayaan Murabahah, Mudharabah, dan Musyarakah terhadap Return on Asset Studi Kasus pada PT Bank Muamalah Indonesia TBK. Periode 2015-2018. Human Falah, 6(1), 19-36.

Hidayati, A. N. (2014). Pengaruh Inflasi, BI Rate dan Kurs terhadap Profitabilitas Bank syariah di Indonesia. An-Nisbah, 01(46), 72-97.

Mahmudah, N., \& Harjanti, R. S. (2016). Analisis Capital Adequacy Ratio, Financing to Deposit Ratio, Non Performing Financing, dan Dana Pihak Ketiga terhadap Tingkat Profitabilitas Bank syariah Periode 2011-2013. Seminar Nasional Iptek Terapan, 1(1), 134-143.

Majid, M.S.A., \& Ulina, S. (2020). Does the 2008-Global Financial Crisis Matter for the Determinants of Conventional and Islamic Banking Performances in Indonesia? Jurnal Ekonomi dan Kenangan Islam, 6(2), 77-90. https://doi.org/10.20885/JEKI.vol6.is s2.art1

Menicucci, E., \& Paolucci, G. (2016). The Determinants of Bank Profitability: Empirical Evidence from European Banking Sector, Journal of Financial Reporting and Accounting, 14(1), 86-115, https://doi.org/10.1108/JFRA-05-2015-0060

Muhaemin, A., \& Wiliasih, R. (2016). Analisis Faktor-Faktor yang Memengaruhi Profitabilitas Bank Pembiayaan Rakyat Syariah di Indonesia. Jumal Nisbah, 2(1), 180-206. http://ojs.unida.ac.id/index.php/JN/article/ view/255.

Muhammad, R., \& Triharyono, C (2019). Analysis of Islamic Banking Financial Performance Before, During and After Global Financial Crisis. Jurnal Ekonomi dan Kenangan Islam, 5(2), 80-86. https://doi.org/10.20885/JEKI.vol5.iss2.art5

Nasution, Z. (2020). Profit efficiency development of Islamic Banking using stochastic frontier approach. Jurnal Ekonomi dan Keuangan Islam, 6(1), 55-63. https://doi.org/10.20885/JEKI.vol6.iss1.art6 
Otoritas Jasa Keuangan. 2020. Daftar Statistik Perbankan Syariah Bulanan. Diakses pada 10 Oktober 2020, dari www.ojk.go.id

Rahman, A. F., \& Rochhmanika, R. (2012). Pengaruh Pembiayaan Jual Beli , Pembiayaan Bagi Hasil , dan Rasio Non Performing Financing terhadap Profitabilitas Bank syariah di Indonesia. Iqtishoduna, Jurnal Ekonomi dan Bisnis Islam, 8(1), 27-53. https://doi.org/https://doi.org/10.18860/iq.v0i0.1768

Rahman, T., \& Fatmawati, K. (2020). The Influence of Financial Ratios on Non Performing Financing of The Sharia Rural Banks of Special Regions of Yogyakarta (BPRS DIY) Period 2015-2018, Asian Journal of Islamic Management, 2(1), 25-35. https://doi.org/10.1108/AJIM.vol2.iss1.art3

Romdhoni, A. H., \& Yozika, F. El. (2018). Pengaruh Pembiayaan Mudharabah, Musyarakah dan Ijarah terhadap Profitabilitas Bank Muamalat Indonesia. Jurnal Ilmiah Ekonomi Islam, 4(3), 177-186. https://doi.org/10.29040/jiei.v4i03.314

Sahara, A. Y. (2013). Analisis Pengaruh Inflasi, Suku Bunga BI, dan Produk Domestik Bruto terhadap Return on Asset (ROA) Bank syariah di Indonesia. Jurnal Ilmu Manajemen (IIM), 1(1), 149-157.

Setiawan, U.N.A., \& Andriani, A. (2016). Pengaruh Dana Pihak Ketiga (DPK), Capital Adequacy Ratio (CAR), dan Non Performing Financing (NPF) terhadap Profitabilitas Bank Syariah dengan Pembiayaan sebagai Variabel Intervening, Diponegoro Journal of Management, 5 (4), 1-11.

Sudarsono, H. (2017). Analisis Pengaruh Kinerja Keuangan terhadap Profitabilitas Bank syariah di Indonesia. Economica: Jurnal Ekonomi Islam, 8(2), 175-203. https://doi.org/10.21580/economica.2017.8.2.1702

Sudarsono, H., Mifrahi, M.M., Susantun, I., Rudatin, A., \& Ruchba, S.M. (2019). Analysis of Factor Affecting Financing with Islamic Banks in Agriculture Sectors. Asian Journal of Islamic Management, 1(1), 80-100. https://doi.org/10.1108/AJIM.vol1.iss2.art6

Sudarsono, H., Nugrohowati, R, N, I., \& Tumewang, Y. K. (2020). The Effect of Covid-19 pandemic on the Adoption of Internet Banking in Indonesia: Islamic Bank and Conventional Bank, The Journal of Asian Finance, Economics and Business, 7 (11), 789-800. https://doi.org/10.13106/jafeb.2020.vol7.no11.789

Sumarlin. (2016). Analisis Pengaruh Inflasi, CAR, FDR, BOPO, dan NPF terhadap Profitabilitas Perbankan Syariah. Assets, Jurnal Ekonomi, Manajemen dan Akuntansi, 6,(36), 296-313.

Syahri, N. A., \& Harjito, D A. (2020). The effect of financing using the principle of profit-loss sharing on profitability level of commercial Islamic bank registered in Bank Indonesia, Asian Journal of Islamic Management, 2(1), 46-58. https://doi.org/10.1108/AJIM.vol 2.iss1.art5

Tumewang, Y.K., Nugrohowati, R.N.I., \& Musta'in, J.L. (2019). The impact of macro economy toward profitability of Islamic bank. Asian Journal of Islamic Management, 1(2), 101-108. DOI: 10.1108/AJIM.vol1.iss2.art4

Ubaidillah. (2016). Analisis Faktor-Faktor yang Mempengaruhi Profitabilitas Bank syariah di Indonesia. Jurnal Ekonomi Islam, 4(1), 151-188.

Wibowo, E. S., \& Syaichu, M. (2013). Analisis Pengaruh Suku Bunga, Inflasi, CAR, BOPO, NPF terhadap Profitabilitas Bank syariah. Diponegoro Journal of Management, 2(2), 10-19.

Widarjono, A. (2018). Ekonometrika Pengantar dan Aplikasinya disertai Panduan EViews (5th ed.). UPP STIM YKPN.

Widarjono, A. (2020). Does the Volatility of Macroeconomic Variables Depress the Profitability of Islamic Banking, Jejak, Journal of Economics and Policy, 13(1), 30-42. https://doi.org/10.15294/jejak.v13i1.19460

Yundi, N, F., \& Sudarsono, H. (2018). Pengaruh Kinerja Keuangan terhadap Return on Asset (ROA) Bank 
syariah di Indonesia, Al-Amwal, 10(1), 18-31, DOI: 10.24235/amwal.v10i1.2759

Yusuf, M. Y., \& Mahriana, S. (2016). Faktor -Faktor yang Mempengaruhi Tingkat Profitabilitas Bank Pembiayaan Rakyat Syariah (BPRS) di Aceh, Iqtishadia: Jumal Kajian Ekonomi dan Bisnis Islam 9 (2): 246. https://doi.org/10.21043/iqtishadia.v9i2.1731. 